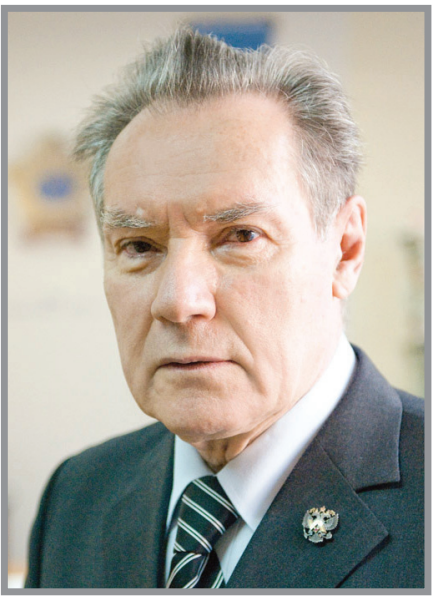

GUSEV Boris Vladimirovich,

President of Russian Academy of Engineering

and International Academy of Engineering,

Corresponding Member of RAS, expert of

RUSNANO, Honoured Scientist of RF, Laureate

of USSR and RF State prizes, Doctor in Technical

Sciences, Professor. 9, bld. 4, Gazetny Pereulok,

125009, Moscow, Russia

e-mail: info-rae@mail.ru

\title{
RUSSIAN ACADEMY OF ENGINEERING: A STRONG POWER FOR INTEGRATION OF ENGINEERING COMMUNITY
}

Russian Academy of Engineering is legal successor of the Engineering Academy of USSR, founded by 20 ministries and departments of USSR and RSFSR on May 13, 1990. The Engineering Academy of USSR since the very beginning of its functioning, has launched its task-oriented activity on strengthening of links between science and industry, on solving the problems of using the results of basic (fundamental) research and their accelerated adaptation into the industry. In the post-Soviet period, on the basis of the Academy, the Ministry of Justice of the Russian Federation, on December 24, 1991, registered the All-Russian Public Organization Russian Academy of Engineering (RAE).

At the present time, RAE includes over 1350 full and corresponding members, prominent Russian scientists, engineers and industry organizers, over 200 member societies which include major Russian science \& technology organizations, and over 40 regional engineering-technical structures, departments of RAE. RAE carries out large-scale work on the development of science \& technology areas in science, creating new machinery and technologies, organization of efficient functioning of the Russian Engineering community.

During the 25-year period of work, about 4,5 thousand new technologies were developed, over 6,5 thousand monographs were published. Over 4 thousand 
patents were obtained. 209 members of RAE became laureates of State Prize of USSR and RF, 376 members of RAE became laureates of Government Prize of USSR and RF. Annual value of science \& research, project and other works in the area of engineering amounts from 0,5 to 1 billion roubles.

This information and reference edition of the Encyclopedia of the Russian Academy of Engineering is dedicated to the $25^{\text {th }}$ anniversary of the Russian Academy of Engineering.

The Encyclopedia includes creative biographies of more than 1750 full and corresponding members of RAE, prominent scientists, distinguished engineers and organizers of industry, elected into the Academy since the foundation. The Encyclopedia provides information of people who in the end of $\mathrm{XX}$ and in the beginning of XXI centuries actively contributed to retaining and development of intellectual potential of science \& technology on the main engineering directions by efficient implementation of achievements of fundamental science in the industry.

Key words: Russian Academy of Engineering, Engineering community, Engineering activities, fundamental research, models of new machinery, new technologies, science \& technical areas of science, application of nanotechnologies and nanomaterials.

DOI: dx.doi.org/10.15828/2075-8545-2015-7-2-15-46

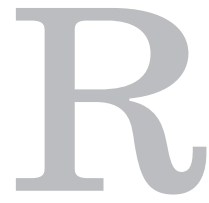

ussian Academy of Engineering is legal successor of the Engineering Academy of USSR, founded by 20 ministries and departments of USSR and RSFSR on May 13, 1990.

The initiative of founding Engineering Academy of USSR was put forward by prominent Soviet scientists: full members of USSR Academy of Sciences A.Yu. Ishlinsky, G.A. Nikolaev, I.A. Glebov, and K.V. Frolov. This initiative was repeatedly discussed in central Party and State structures of the country. However, the decision on establishing the Academy was not taken.

At the same time, science \& technology community, understanding the importance of founding the single structure consolidating engineering community of the country, started active process on establishing such a structure under various other names. 
Following the serious preparation efforts, first of all, among the organizations of the Union of Science \& Technology Societies of USSR and a range of major Scientific \& Research Institutes, the USSR Federation of Engineers was established.

Within the Federation, the organizing committee on forming Engineering Academy of USSR was founded (chaired by the Vice President of the USSR Federation of Engineers B.V. Gusev), carrying out in 1989-1990 active and fruitful efforts on preparing public opinion in all former USSR. As a result, on the First General Meeting of the Engineering Academy of USSR (Protocol №1 of March 24, 1990), the Charter was adopted. First 25 full members of the Engineering Academy of USSR were elected, and the first President of the Academy, B.V. Gusev.

According to the decision of Timiryazev district Soviet of People's Deputies of May 13, 1990, the first registration of the Engineering Academy took place.

Taking into consideration that obtaining recognition without support of State Structures may be a difficult task, the Presidium of the Academy

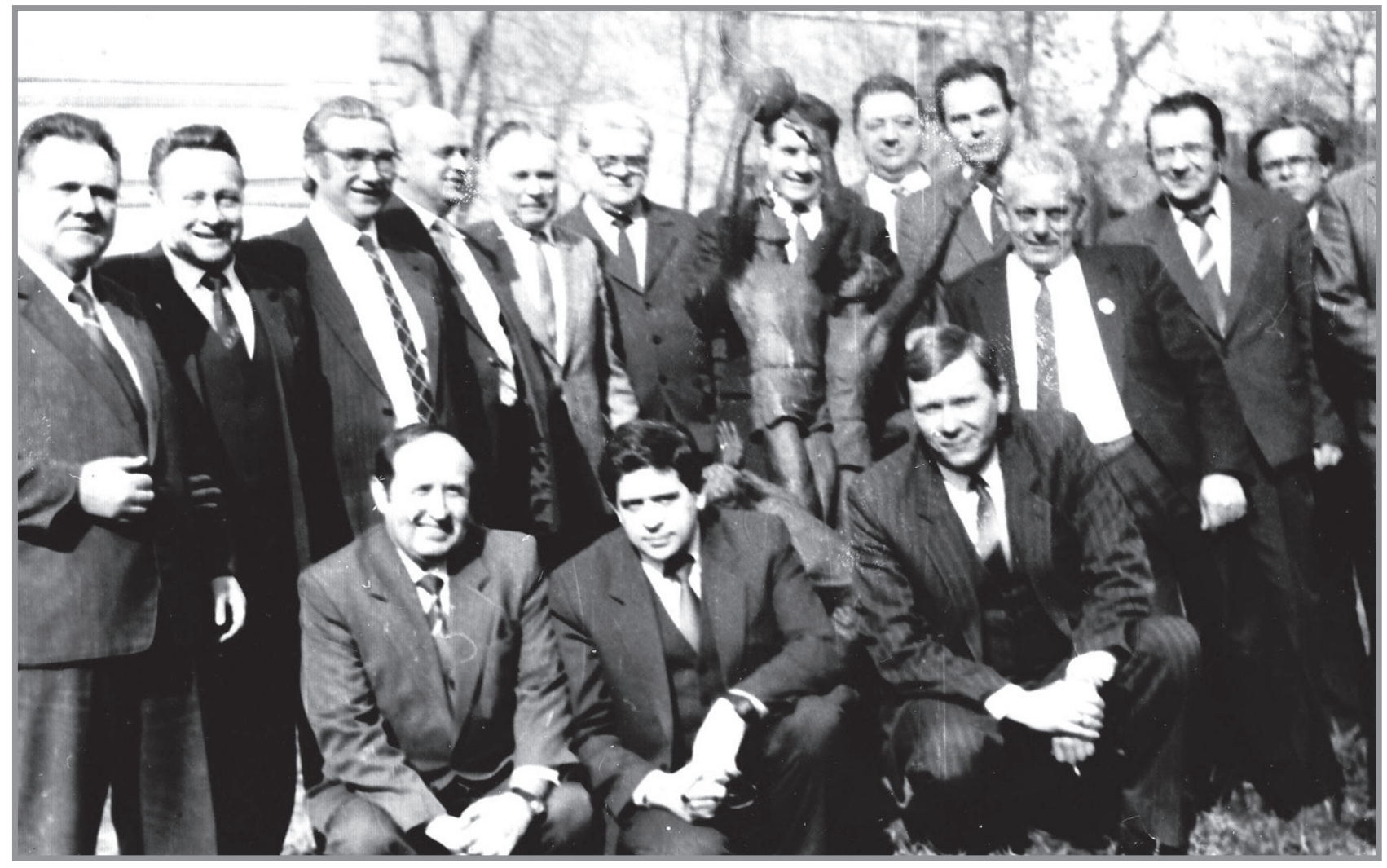

First members of the Engineering Academy of USSR (March 24,1990) 
took active efforts on the approval of the Charter of the Academy in ministries and departments of USSR and RSFSR. On May 21, 1990, the Charter of the Academy of Engineering was approved in Ministry of Higher Educational Institutions of RSFSR, and after that, respectively: on May, 29, Ministry of Automotive and Agricultural Engineering of USSR, and State Forest Committee of USSR, on June, 1, Ministry of Electric Industry of USSR, on June, 7, Ministry of Oil and Gas Construction of USSR, and Soyuzstroymaterialy (Union Construction Materials), on June, 13, Ministry of Energy of USSR and Ministry of Urals and Siberian Construction of RSFSR, on June, 15, Ministry for Medical Industry of USSR, on June, 16, Ministry for Transport Engineering of USSR and Ministry of North-Western Construction of RSFSR, on June, 19, Ministry for Special-Purpose Construction of USSR and Ministry of Eastern Construction of RSFSR, on June, 24, Ministry for Marine Vessel Engineering of USSR, and later, in other ministries and departments.

The Charter was approved by the Ministers (heads of departments) or Deputy Ministers (deputy heads of departments): O.G. Anfimov, Yu.P.Batalin, B.N. Belousov, I.N. Bukreev, V.M. Velichko, V.N. Zabelin, S.V. Kolpakov, E.B. Levichev, A.I. Makarenko, Yu.L. Nazarov, I.F. Obraztsov, N.A. Panichev, E.K. Pervyshin, P.A. Polad-Zade, V.I. Reshetilov, G.B. Stroganov, V.I. Sukhikh, E.V. Filippov, V.S. Chernomyrdin, V.G. Chirskov, M.S. Shkabardnya, M.I. Shchadov and others.

Great support in establishing and development of the Engineering Academy of USSR was provided by the State Committee of USSR on Science and Technology (Academician N.P. Laverov), USSR Academy of Sciences (Academician G.I. Marchuk), Presidium of the Union of Science \& Engineering Societies of USSR (Academician A. Yu. Ishlinsky), and the Board of Science \& Industry Union of USSR (A.I. Volsky).

Considerable contribution to the organizing of the Academy functioning was made by the Full members of USSR Academy of Sciences: A. Yu. Ishlinsky, B.E. Paton, K.V. Frolov, and the Council of Elders which consisted of Full members of USSR Academy of Sciences. Co-chairs of the Council of Elders of the Academy were elected: A.Yu. Ishlinsky, I.A. Glebov, and the members of the Council: S.V. Vonsovsky, D.G. Zhimerin, B.P. Zhukov, N.N. Kovalev, K.S. Kolesnikov, Ya. M. Kolotyrkin, S.V. Kolpakov, V.A. Kotelnikov, N.D. Kuznetsov, B.N. Laskorin, G.F. Nikolaev, B.E. Paton, G.P. Svishchev, K.S. Silin. 
Among prominent state figures and industry organizers, outstanding scientists and engineers contributed in establishing of the Academy, are: S.A. Abdraimov, V.N. Antsiferov, Yu.P. Batalin, V.M. Bondarenko, B.V. Budzulyak, I.N. Bukreev, S.N. Bulgakov, A.I. Vasiliev, Yu.S. Vasiliev, L.I. Volkov, I.I. Vorovich, U.A. Dzholdasbekov, B.T. Zhumagulov, V.K. Kabulov, V.Ya. Karelin, I.P. Ksenevich, G.E. Lozino-Lozinsky, A.F. Mekhtiev, I.V. Prangishvili, B.S. Sazhin, Yu. P. Samarin, A.N. Semenov, A.I. Fedotov, Yu. E. Khodzhamiryan, Yu. A. Yashin.

The example of government recognition became the adoption, on August 22, 1991, of the Resolution of the State Committee of USSR on Science and Technology, signed by the Deputy Chair of Counsil of Ministers of USSR, Chair of the State Commission on Science and Technology, Full member of USSR Academy of Sciences N.P. Laverov "Of the Engineering Academy of $\boldsymbol{U S S R}$ ". According to this resolution, over 100 scientific-production enterprises, scientific-research institutes and design bureaus were delivered under scientific and methodological administration of the Academy.

To the end of 1991, strong basis of the Academy was founded: 338 full and corresponding members from 10 republics of USSR were elected. Among the members of the Academy are leading scientists and teachers, prominent organizers of science, education and industry, who made great contribution in scientific and engineering development of various branches of national economy.

In 1990-1991, active process on establishing first branches of the Engineering Academy of USSR has started. According to the Resolutions of the Presidium of the Engineering Academy of USSR, were created Leningrad branch (June 18, 1990), South Ukrainian (August 30, 1990), Urals (September 30, 1990), Turkmen (November 12, 1990), Altai and Dnieper (January 17, 1991), Tomsk, Kuzbass, Omsk, Gomel, Perm (March 14, 1991). In April, 1991, new regional departments began to form, and the functioning branches of the Academy were extended. In this period, Leningrad, Siberian, Urals, Ukrainian, Kazakhstan, Tajikistan, Turkmenistan, Kyrgyzstan, and other departments of the Academy.

The Engineering Academy of USSR since the very beginning of its functioning, has launched its task-oriented activity on strengthening of links between science and industry, on solving the problems of using the results of basic (fundamental) research and their accelerated adaptation into the industry. 
In the post-Soviet period, on the basis of the Academy, the Ministry of Justice of the Russian Federation, on December 24, 1991, registered the All-Russian Public Organization Russian Academy of Engineering (RAE), and on February 10, 1992, the International Academy of Engineering (IAE) was registered. The President of RAE and IAE was elected B.V. Gusev.

In 1993, RAE gained consultative status in UNIDO (UN on industrial development), and in 1997, was included in UNESCO among the expert organizations on new technologies in Central and Eastern Europe. In 2001 and 2004, RAE successfully passed state accreditation in Russian Federation.

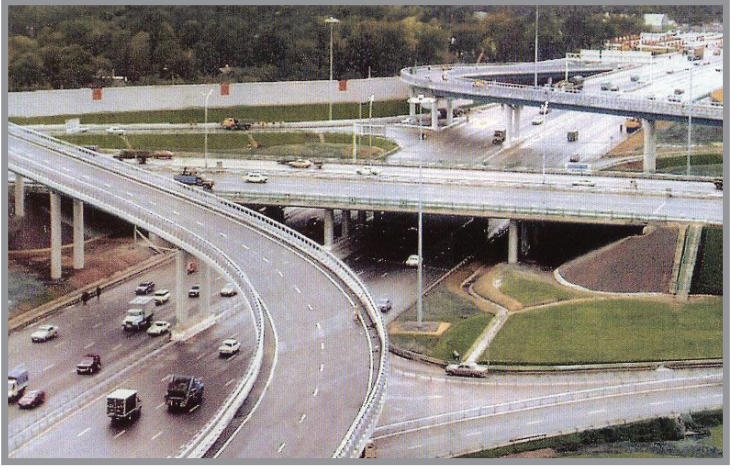

Highway junction in Moscow. Crossing of Moscow Ring Highway (patent of RAE)

At the present time, RAE includes over 1350 full and corresponding members, prominent Russian scientists, engineers and industry organizers, over 200 member societies which include major Russian science \& technology organizations, and over 40 regional engineering-technical structures, departments of RAE.

RAE carries out large-scale work on the development of science \& technology areas in science, creating new machinery and technologies, organization of efficient functioning of the Russian Engineering community.

During the 25-year period of work, about 4,5 thousand new technologies were developed, over 6,5 thousand monographs were published. Over 4 thousand patents were obtained. Significant number of articles were published. Here are mentioned some of them, dedicated to applying nanotechnologies and nanomaterials [1-26]. 209 members of RAE became laureates of State Prize of USSR and RF, 376 members of RAE became laureates of Government Prize of USSR and RF. Annual value of science \& research, project and other works in the area of engineering amounts from 0,5 to 1 billion roubles.

Among the priority areas of RAE activity are:

- informatization of society on the basis of using up-do-date information technologies;

- design of systems for monitoring of operating conditions of complexes and systems of various purpose; 
- using double-purpose products and technologies in creating high-tech products, and diversification of defence \& industry complex;

- industrial applications of nanotechnologies and nanomaterials.

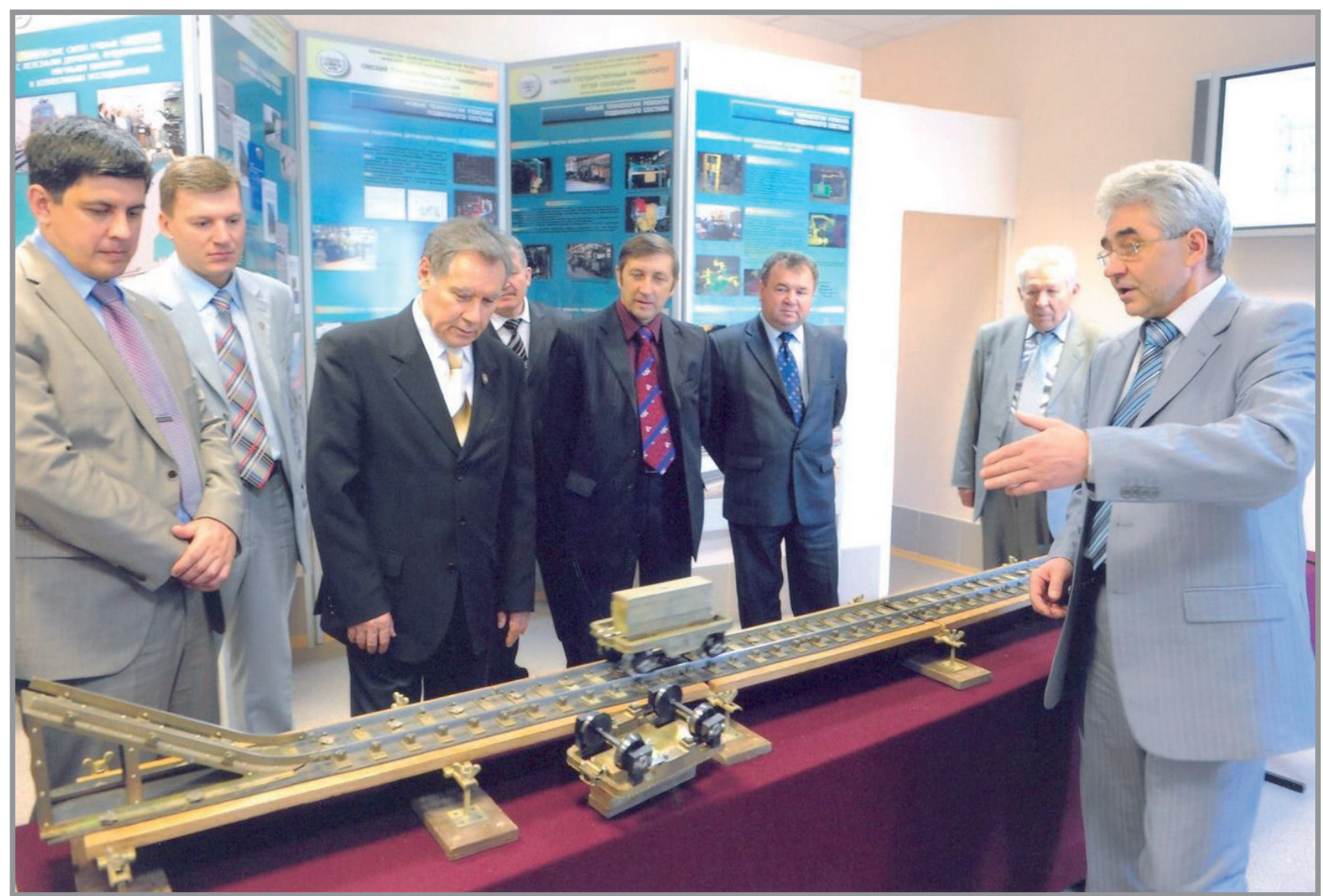

Exit session of the Presidium of $R A E$ in Omsk

But, undoubtedly, the main direction of RAE activity on which major project are being implied, is machine building. Significant science \& practical research were carried out by the members of the Academy in the field of shipbuilding, first of all, on the basis of the enterprise «Admiralteyskie Verfi» («Admiralty shipyards»): new classes of arctic vessels have been created, including dry cargo ships with capability of performing ice-breaker functions in ice with thickness up to 2 meters. In partnership with companies of the leading industrial countries, the Academy takes active part in creating complex marine information and robotized underwater complexes-robots. The essence of the project is modernization of underwater technical services on continental shelf, in ports, lakes and waterways. 
The Russian Academy of Engineering carries out wide-scale work on materials science. This is, first of all, the creation of new technologies and materials in various fields of industry:

- aviation \& space - highly-reliable elements of structures on the bases of wide range of carbon, aramide, and other types of fibres (high-modular reinforced composite materials);

- for machine-building - new types of steels and light alloys;

- for construction industry - various types of steels and concretes, resistant to low temperatures and various aggressive mediums.

For example, the using of protective coatings for concretes and metals considerably increases their strength, and their durability may be increased $3 \ldots 7$ times. The results of the research were widely used in practice, particularly, in construction of Olympic structures in Sochi.

New construction solutions have been actively developed, including for operating of structures in seismic conditions and in the areas of per-

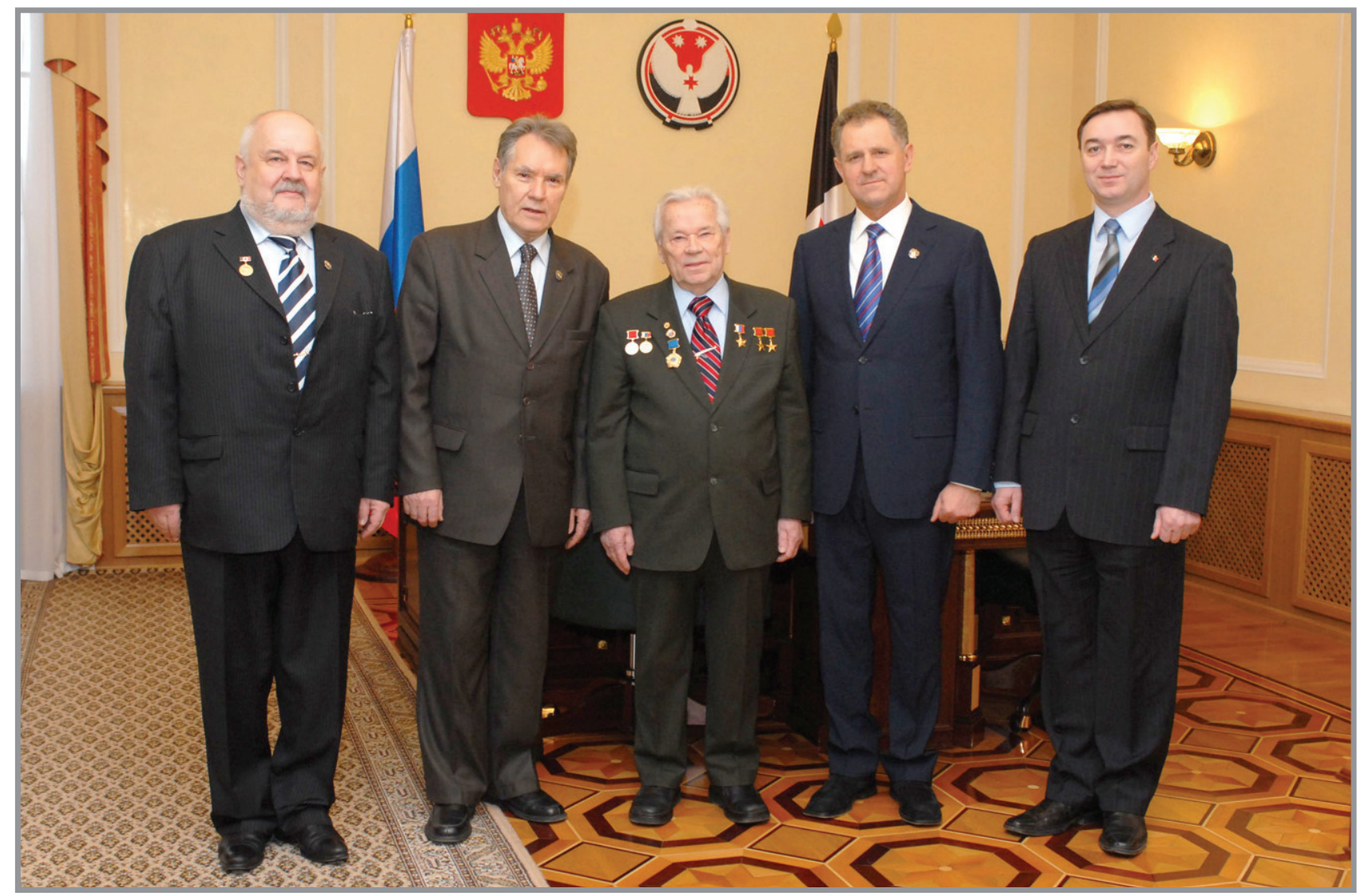

Meeting with M.T. Kalashnikov in the cabinet of the President of Udmurt Republic, A.A.Volkov (Izhevsk) 
mafrost, for increase of resistant capability of structures and buildings, additional pre-stressing with reinforcement of the building with ropes during construction. For the estimate of condition of reliability of structures and buildings (dams, power stations etc.), estimate of weak points or places which may be in unfavourable conditions during seismic influence, new technologies of 3D measurements were proposed.

In the area of energy and resource-saving, solutions are being offered on development of power installations with efficiency coefficient over $70 \%$, and heat exchangers - over $90 \%$, as well as transition from central heat systems to mobile heating systems. Development of using alternative energy sources includes usage of wind power generators, cavitation heaters for heat networks etc.

In the Academy, wave technologies have been widely studied; use of such technologies allows to create various modes, including bioresonance modes in emulsions and suspensions, and provide obtaining of materials of high degree of homogeneity. Special attention is paid to use of wave technologies for modification gasoline and diesel fuel. Interleaving emulsions

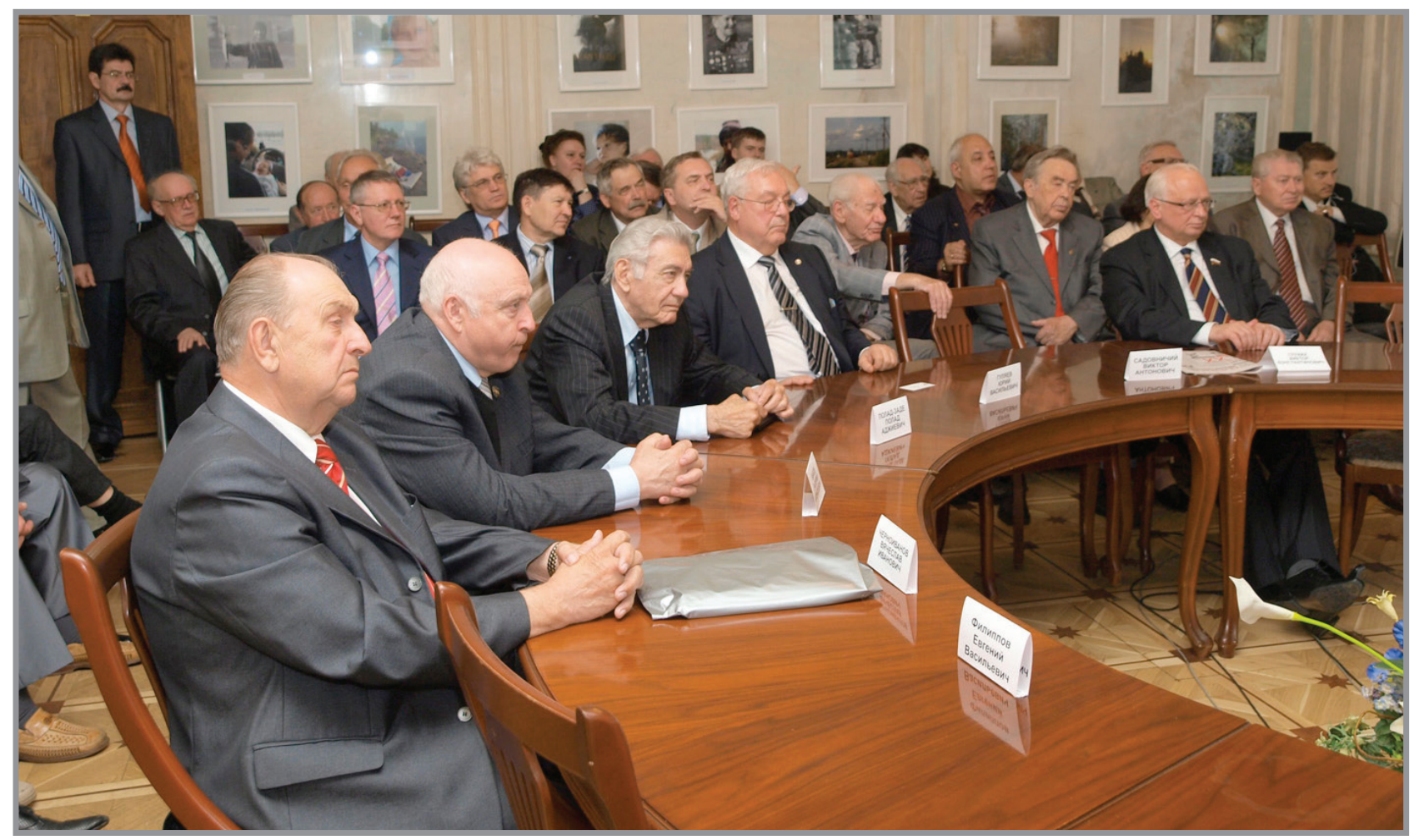

20-year anniversary of the Russian Academy of Engineering (in the first row, Ministers-Founders) 
of «fuel-water» types on wave generators have been obtained, what makes it possible to increase octane number of fuel, at the same time decreasing harmful emissions into atmosphere of carbonic and nitric oxide. Technologies for synthesis of biogas in reactors of new types have been developed: processing of biomass in the reactor of catalytic hydrocracking, what makes it possible to efficiently use in environmentally friendly way natural biological substances for production of combustible gases, heat, and electric power.

The «geography» of scientific \& practical activity of RAE has considerably expanded. Of great theoretical and practical interest, the works of major part of regional structures. Among them are the following:

- $\quad$ projecting of fibre-optical devices (Bashkortostan department);

- usage in various branches of industry, in machinery and technologies, of engineering projects of defence \& industrial complex (Moscow regional department);

- creating guidelines on the estimate of residual life of equipment working under high pressure (Irkutsk department);

- development of methods of synthesis of adaptive and self-adjusting control systems for multiply connected non-linear dynamic systems in conditions of uncertainty and variability of their parameters (Primorye department);

- micro- and nanotribology, creating of nanoelectromechanical systems (Pskov department);

- creating intellectual systems for automation of technological processes (Tomsk department);

- $\quad$ processing technogenic wastes accumulated during 300-year work of Urals industry (Sverdlovsk department);

- design of geophysical complex which allows to trace the existing disposition of foundation soils of structures and buildings, as well as prognosticate the directions of geocryological processes (Yakutian department) etc.

RAE has always been an active organizer of international and all-Russian forums. Among them are: I and II Congresses of Russian Engineers and of the subjects of the Russian Federation, All-Russian Science \& Technology Conference «Reserves of acceleration of economic growth and duplication of GDP», All-Russian Forum "Peaceful Use of Space», international and all-Russian conferences - «Perspective tasks of Engineering Science», 


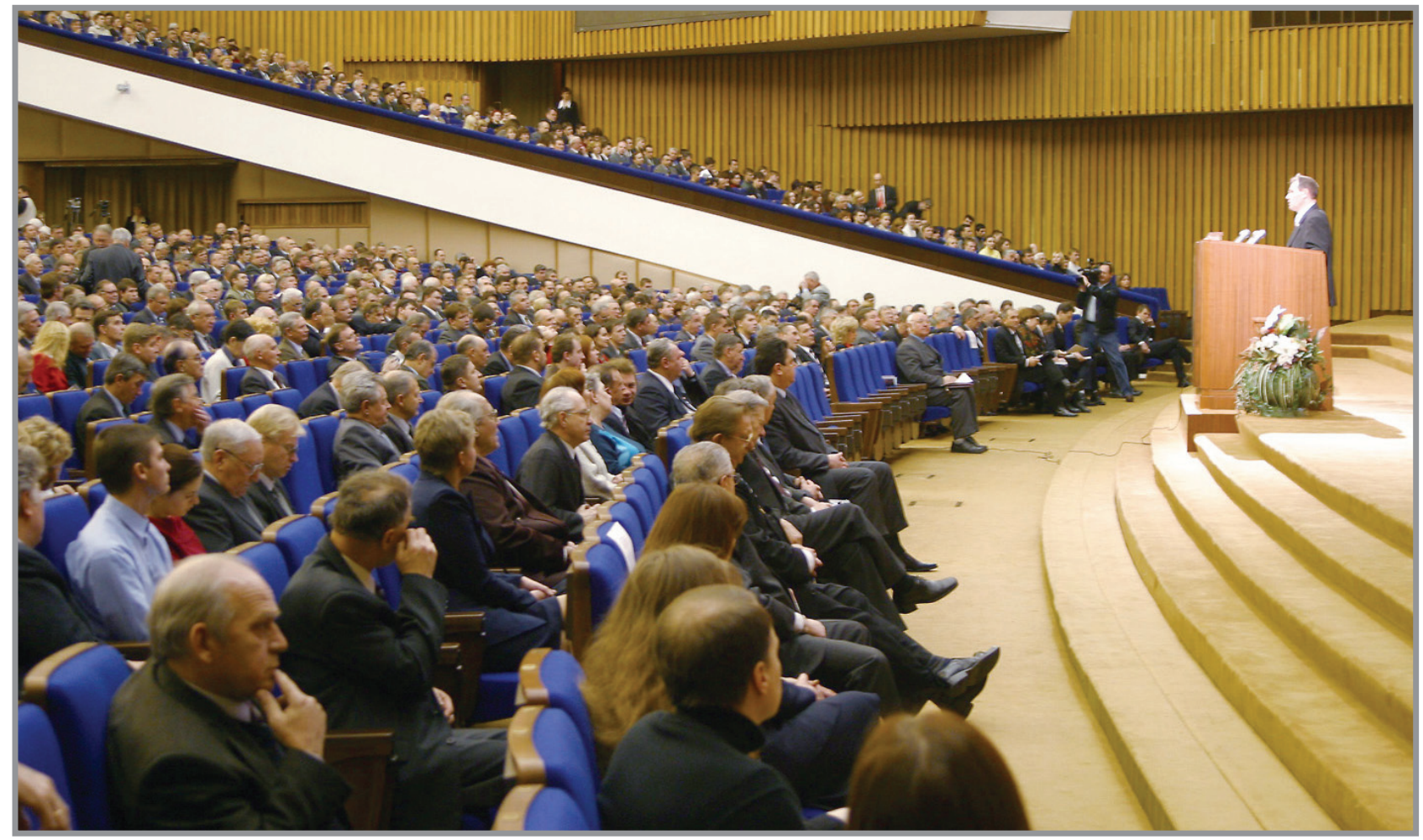

Delegates and participants of I Congress of Russian Engineers in Great Kremlin Hall

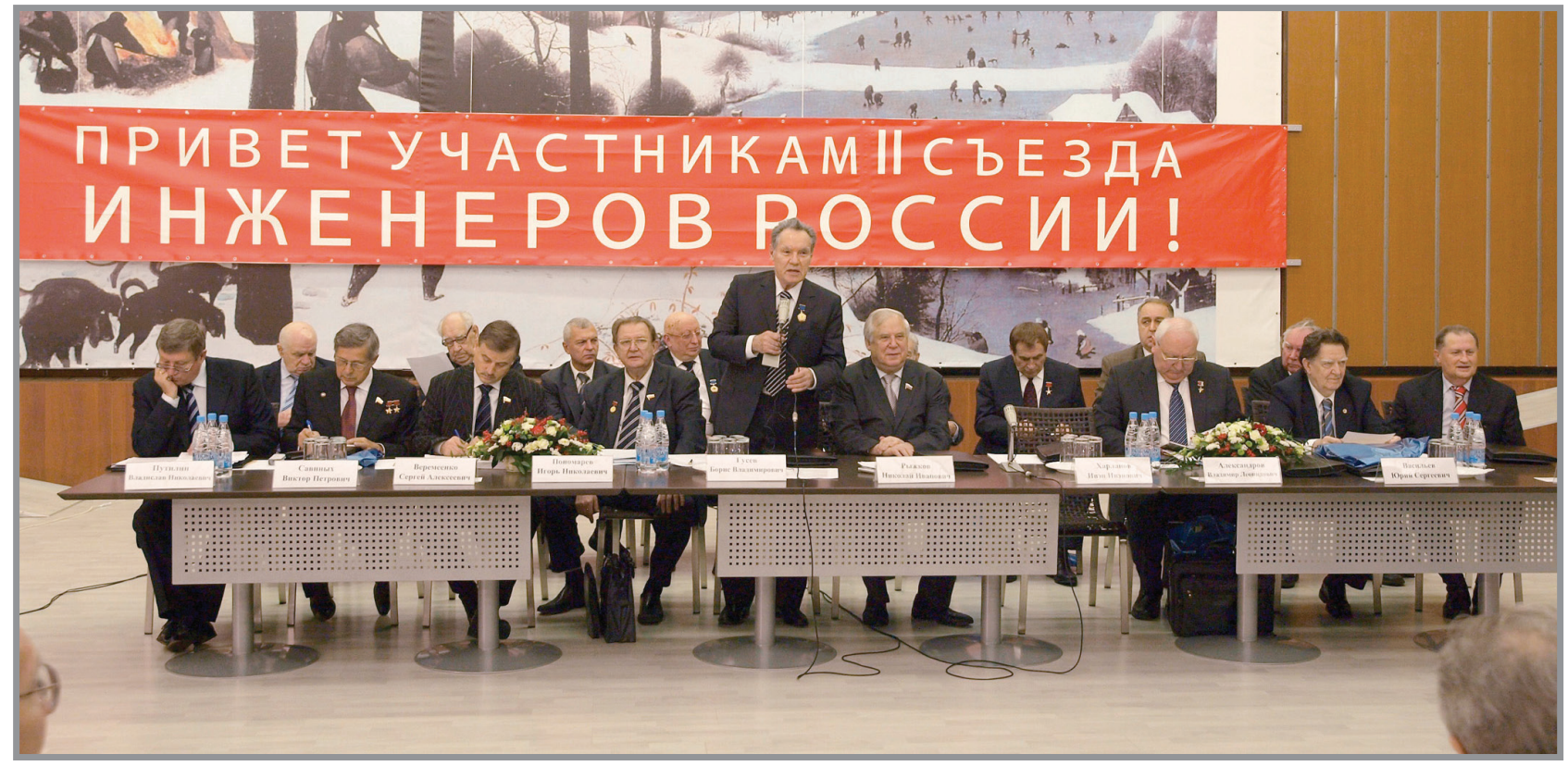

Presidium of II Congress of Russian Engineers (Moscow) 


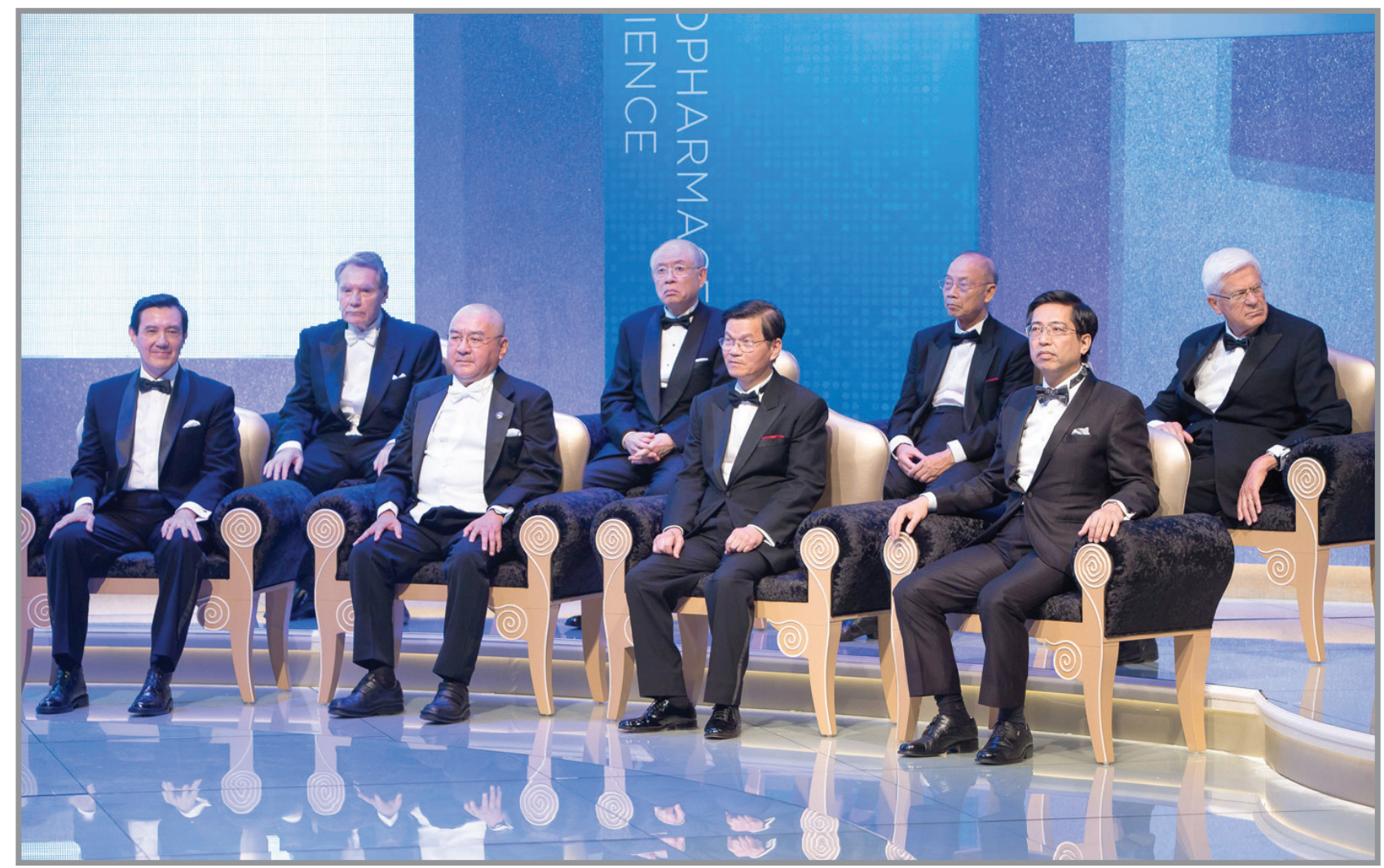

Tang Prize Ceremony, September 2014 (From the left to the right in the first row: President of Taiwan, Ma Ying-jeou; founder of the Tang Prize, Dr. Samuel Yin; President of Academia Sinica, Chi-Huey Wong; CEO of Tang Prize Foundation, Jenn-chuan Chern)

«Theory and Practice of Making Products from Composite Materials and New Metal Alloys», "Small and Alternative Energy, Energy Efficiency», «Concrete and Reinforced Concrete - a Glance Into the Future», Scientific \& Practical Online Conference «Use of Nanotechnologies in Construction», specialized exhibitions and conferences «Double-Purpose Products and Technologies», "Diversification of Defence \& Industrial Complex» and others. RAE participates in publishing of «Engineering Newspaper», Inter-industry Almanac «Business Glory of Russia», online edition "Nanotechnologies in Construction: Scientific Online Magazine», as well as over 20 science \& technology magazines.

This information and reference edition of the Encyclopedia of the Russian Academy of Engineering is dedicated to the $25^{\text {th }}$ anniversary of the Russian Academy of Engineering. 
РОССИЙСКАЯ ИНЖЕНЕРНАЯ АКАДЕМИЯ

ЭНЦИКЛОПЕДИЯ

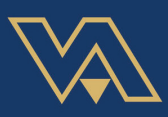

2015
The Encyclopedia includes creative biographies of more than 1750 full and corresponding members of $\mathrm{RAE}$, prominent scientists, distinguished engineers and organizers of industry, elected into the Academy since the foundation. The Encyclopedia provides information of people who in the end of XX and in the beginning of XXI centuries actively contributed to retaining and development of intellectual potential of science \& technology on the main engineering directions by efficient implementation of achievements of fundamental science in the industry. These are, first of all, honorary presidents and honorary members of the RAE, members of the Academy, of which the information is provided.

The edition provides information of the foreign members of the RAE, whose scientific and industrial achievements contribute to the enhancing of the prestige of the Academy worldwide.

Among the main goals of the Encyclopedia is forming wide and sustainable public interest to science and technology, increase professional interest of science workers, engineers and students, as well as professional orientation of pupils on deliberate choice of engineering profession. To simplify the search, the information is provided in alphabetical order.

RAE takes active part not only in the solving issues of technological development of the country. On the stage of forming higher professional school, serious efforts were taken for retaining engineering education in Russia (over $1 / 3$ of the members of RAE work directly in the area of professional education). The issues of estimate of the state and choosing the main directions of development of professional education were reflected in preparing proposals for the Russian Presidential Commission on Modernization.

Undoubtedly, for the purpose of use of intellectual potential of scientific and engineering structures, the priority task for RAE is provision of 
constructive interaction with federal and regional organs of legislative and executive power, as well as creating efficient mechanisms of interaction of society, business and government, directed to the coordination of common efforts in elaboration and implementation of national social-economical policy.

The Russian Academy of Engineering initiates active integration of the engineering community in Russia, and in the countries of near and far abroad. The Academy is a kind of a generator of new ideas which assist the development of both engineering directions of real sector of national economy, and social-economical development of society. The role of RAE in solving urgent issues on development theoretical and practical bases for creating principally new technological structure, based on the economy of knowledge and competitiveness in all branches of modern industrial and agrarian sectors, continues to grow.

\section{DeAR COLleagues!}

THE REFERENCE TO THIS PAPER HAS THE FOLLOWING CITATION FORMAT:

Gusev B.V. Russian Academy of Engineering: a strong power for integration of engineering community. Nanotehnologii v stroitel'stve $=$ Nanotechnologies in Construction. 2015, Vol. 7, no. 2, pp. 15-46. DOI: dx.doi.org/10.15828/2075-85452015-7-2-15-46. 


\section{References:}

1. Gusev B.V. Development of nano-science and nano-technologies. Industrial and Civil Engineering. 2007, № 4, pp. 45-46.

2. Ivasyshin H.S. Nauchnye otkrytija v mikro- i nanotribologii [Scientific discoveries in micro- and nanotribology]. Mezhotraslevoj al'manah. Delovaja slava Rossii. Moscow, Slavitsa, 2007. Iss. 3, pp. 47-48.

3. Ponomarenko A.T., Figovsky O., Shevchenko V.G. Multifunctional Polymer Composites for «Intellectual» Structures: Present State, Problems, Future. Journal Advanced Materials Research, 2008, Vol. 740 (47), pp. 81-84, Trans Tech.

4. Falikman V.R., Vainer A.Y. Fotokataliticheski aktivnye stroitel'nye materialy s nanochasticami dioksida titana - novaja koncepcija uluchshenija jekologii megapolisov [Photocatalytically active building materials with nanoparticles of titanium dioxide - a new concept to improve the ecology of big cities]. Voprosy primenenija nanotehnologij v stroitel'stve: Cb. dokl. uchastnikov kruglogo stola [The problems of implementation of nanotechnologies in construction: proc. of the round table]. Moscow, Moscow State University of Civil Engineering, 2009, pp. 35-49.

5. Falikman V.R. About the use of nanotechnologies and nanomaterials in construction. Part 1. Nanotehnologii v stroitel'stve $=$ Nanotechnologies in Construction. 2009, Vol. 1, no. 1, pp. 24-34. Available at: http://nanobuild.ru/en_EN/(date of access: 12.03.2015). (In Russian)

6. Gusev B.V., Minsadrov I.N., Miroevsky P.V. et al. Investigation of nanostructuring processes in finegrained concretes with silicon dioxide nanoparticles admixture. Nanotehnologii v stroitel'stve = Nanotechnologies in Construction. 2009, Vol. 1, no. 3, pp. 8-14. Available at: http://nanobuild.ru/ en_EN/ (date of access: 12.03.2015). (In Russian)

7. Ivasyshin H.S. Scientific discoveries in micro- and nanotribology. Phenomenological fundamentals of quantum friction theory. Nanotehnologii v stroitel'stve $=$ Nanotechnologies in Construction. 2010, Vol. 2, № 4, pp. 70-86. Available at: http://nanobuild.ru/en_EN/ (date of access: 12.03.2015). (In Russian)

8. Falikman V.R., Sobolev K.G. «There's plenty of room at the bottom», or how nanotechnologies can change the world of concrete. Part 1 . Nanotehnologii v stroitel'stve = Nanotechnologies in Construction. 2010, Vol. 2, no. 6, pp. 17-31. Available at: http://nanobuild.ru/en_EN/ (date of access: 12.03.2015). (In Russian)

9. Ivasyshin H.S. Scientific discoveries in micro- and nanotribology and helium wear. Nanotehnologii v stroitel'stve $=$ Nanotechnologies in Construction. 2011, Vol. 3, № 3, pp. 49-66. Available at: http://nanobuild.ru/en_EN/(date of access: 12.03.2015). (In Russian)

10. Falikman V., Vajner A., Zverev $I$. New photocatalytic cementitious composites containing modified titanium dioxide nanoparticles. Proceedings of the 3rd Int. Symposium on High Performance Concrete and Nanotechnology for High Performance Construction Materials (Hipermat), 7-9 March 2012, Kassel, Germany, pp. 147-152.

11. Bazhenov Yu.M., Garkina I.A., Danilov A.M., Korolev E.V. System analysis in Construction Material Science. Moscow: Moscow State University of Civil Engineering. 2012. 432 p. (In Russian)

12. Figovsky O.L., Beilin D.A, Ponomarev A.N. Successful implementation of nanotechnologies in building materials. Nanotehnologii v stroitel'stve $=$ Nanotechnologies in Construction. 2012, Vol. 4, no. 3, pp. 6-21. Available at: http://nanobuild.ru/en_EN/ (date of access: 12.03.2015). (In Russian) 
13. Falikman V.R., Petushkov A.V. Development of Russian Market of Nanotechnology Construction Products till 2020. Nanotechnology in Construction: 4th International Symposium. Agios Nicolaos. Crete: Greece. 2012. May 20-22. 120 p. CD. p. 112.

14. Falikman V.R. Nanomaterials and nanotechnologies in modern concretes. Industrial and Civil Engineering. 2013, № 1, pp. 31-34.

15. Gusev B.V., Falikman V.R., Leistner S. et al. Industrial technological research «Development of Russian market of nanotechnological products in construction until 2020». Part 1. A statement of the task and an approach to realize the project. Nanotehnologii $\mathrm{v}$ stroitel'stve $=$ Nanotechnologies in Construction. 2013, Vol. 5, no. 1, pp. 6-17. Available at: http://nanobuild.ru/en_EN/ (date of access: 12.03 .2015$)$. (In Russian)

16. Ivasyshin H.S. Physical and mechanical properties of nanomaterials and quantum mechanics. Nanotehnologii v stroitel'stve $=$ Nanotechnologies in Construction. 2013, Vol. 5, № 3, pp. 45-55. Available at: http://nanobuild.ru/en_EN/ (date of access: 12.03.2015). (In Russian)

17. Gusev B.V., Falikman V.R., Leistner S. et al. Industrial technological research «Development of Russian market of nanotechnological products in construction un-til 2020». Part 2. Analysis of the world market. Nanotehnologii v stroitel'stve $=$ Nanotechnologies in Construction. 2013. Vol. 5, no. 2, pp. 6-20. Available at: http://nanobuild.ru/en_EN/ (date of access: 12.03.2015). (In Russian)

18. Falikman V.R., Vainer A.Y. Photocatalytic cementitious composites containing mesoporous titanium dioxide nanoparticles. Nanotehnologii v stroitel'stve $=$ Nanotechnologies in Construction. 2014, Vol. 6, no. 1, pp. 14-26. Available at: http://nanobuild.ru/en_EN/ (date of access: 12.03.2015). (In Russian)

19. Falikman $V$., Vajner $A$. New high performance nanoadditives for photocatalytic concrete: synthesis and study. Nanotehnologii v stroitel'stve $=$ Nanotechnologies in Construction. 2015, Vol. 7, no. 1, pp. 18-28. DOI: dx.doi.org/10.15828/2075-8545-2015-7-1-18-28.

20. Kudryavtsev P., Figovsky O. Nanomaterials based on soluble silicates, ISBN 978-3-659-63556-4, LAP Lambert Academic Publishing, 2014, $241 \mathrm{p}$.

21. Kudryavtsev P., Figovsky $O$. Nanomaterialy na osnove rastvorimyh silicatov [Nanomaterials based on soluble silicates]. ISBN 978-3-659-58361-2. LAP Lambert Academic Publishing. 2014. 155 p. (In Russian)

22. Romm F., Figovsky O. Modeling of Mechanical Properties of Polymeric Systems with Branching/ Crosslinking, Particularly Their Mechanical Resistence and Stability. Macromolecular Theory and Simulations Volume 11, Issue 1, pp. 93-101, January 2002.

23. Romm F., Figovsky O. Statistical polymer method: Modeling of macromolecules and aggregates with branching and crosslinking, formed in random processes, Discrete Dynamics in Nature and Society Vol. 2 (1998), 3, P. 203-208 http://dx.doi.org/10.1155/S1026022698000181.

24. Kudryavtsev P.G., Figovsky O.L. Nanostructured materials, production and application in construction. Nanotehnologii v stroitel'stve $=$ Nanotechnologies in Construction. 2014, Vol. 6, no. 6, pp. 27-45. DOI: dx.doi.org/10.15828/2075-8545-2014-6-6-27-45 (In Russian)

25. Gusev B.V., Petrunin S.Y. Cavitation dispersion of carbon nanotubes and modification of cement systems. Nanotehnologii v stroitel'stve $=$ Nanotechnologies in Construction. 2014, Vol. 6, no. 6, pp. 50-57. DOI: dx.doi.org/10.15828/2075-8545-2014-6-6-50-57 (In Russian)

26. Kudryavtsev P.G., Figovsky O.L. Quasi-homogenous approximation for description of the properties of dispersed systems. The basic approaches to model hardening processes in nanodispersed silica systems. Part I. Statical polymer method. Nanotehnologii v stroitel'stve $=$ Nanotechnologies in Construction. 2015, Vol. 7, no. 1, pp. 29-54. DOI: dx.doi.org/10.15828/2075-8545-2015-7-1-29-54. 